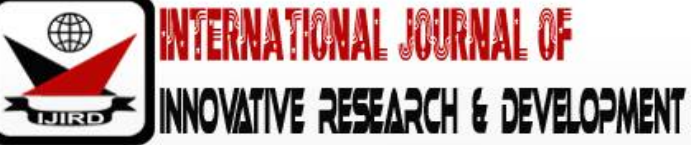

ISSN 2278 - 0211 (Online)

\section{Lecturers Competences and Universities' Students' Skills Acquisition for Employability in South-South Nigeria}

\begin{tabular}{c}
\hline Dr. Ereh, Cecilia Emuji \\
Senior Lecturer, Department Name: Curriculum Studies, Education Management and Planning, \\
University of Uyo, Uyo Akwa Ibom State, Nigeria \\
Okon, Nsikak Mkpong \\
Researcher, Department Name: Curriculum Studies, Education Management and Planning, \\
University of Uyo, Uyo Akwa Ibom State, Nigeria \\
Dr. Umosen, Aloysius Okon \\
Lecturer, Institute of Education and Professional Studies, \\
University of Uyo, Uyo Akwa Ibom State, Nigeria
\end{tabular}

\begin{abstract}
:
The study examined the relationship between Lectures' Competence and Universities Students Skills Acquisition for Employability in South-South Zone, Nigeria. To test hypothesis, purpose along with research questions have been formed. A total of 5817 students from final years in the Faculty of Education have been selected for this study. The test area is the Federal Universities in South-South Zone of Nigeria. The research design has focused on correlational study. Multi-stage sampling technique was used in selecting the sample size of 698 representing $12 \%$ of the study population. A researcher developed two research instruments titled "Lecturers' Competence Questionnaire (LCQ) and Universities Students' Skills Acquisition for Employability Questionnaire (USSAEQ)were used for obtaining primary data.After validation of five validates and reliability checking by Cronbach Alpha Reliability Coefficient instruments have been used for final data collection. Values of .71 for LCQ and .80 for USSAEQ have been found respectively. Confidence interval has been set at 95\%. Mainly Pearson's Product Moment Correlation Statistic has been used for analysis. A significant relationship has been observed between skill of a teacher for major teaching and publication related areas and opportunity of a student for getting job. It was concluded based on the finding that, students' acquisition of employability skills is a function of lecturers' competence. It was recommended based on the finding that, lecturers' competences with regards to knowledge, creativity, discipline, communication, lesson preparation are maintained, students to develop their knowledge, ideas, values and attitudes necessary for successful acquisition of employability skills.
\end{abstract}

Keywords: Lecturers, competence, students, acquisition, skills, employability

\section{Introduction and Background of the Study}

Lecturers are regarded as the most imperative school-based factor that can influence students' achievement levels. Lecturers' competences refers to the ability of a University lecturer to make use of their skills such as communication skills, problem solving skills, teamwork skills, entrepreneurial skills, time management, information communication skills etc. to enhance students understanding of concepts taught.Indonesia Law on teachers and lecturers, 2005 No. 14, discussed capability as a assortment of knowledge and behaviour which must be infatuated by teachers or lecturers. Teachers' 'competency and university students' skills acquisition includes their knowledge, skills, and behaviour which help or improve the capabilities of lecturers to instruct, instruct, direct, teach, and assess the students. According to, Žeravíková, Tirpáková, Markechová (2015), competences should include communication skills, aptitude to learn, conduct social connections, quandary solving, working with ICT or other support tools, and so on. Performance of a job is closely related with proficiency. As per Liakopoulou (2011), knowledge and skills are important component to perform better in a job. Žeravíková et al. (2015), described the teaching process as an important factor which shapes decision making. Competence does not only imply knowledge but also the extent upto which it can be applied. Competency and knowledge both are the ingredients for a successful teacher.

Research of Akiri (2013) in Nigeria revealed that effective teacher can producesuperior student recital. Students' academic performances have strongly association with the teaching skills, subject knowledge, attitudes of teachers (Muzenda, 2013). Positive relation between lecturers' competencies and student performance had been noticed by Long, Kowang, Fei, and Jusoh, (2016). 
Other optimistic associations also reported by Hakim (2015), Sultan and Shafi (2014); Ganyaupfu (2013) and Darling-Hammond (2000).Uganda (Wamala and Seruwagi, 2013) established no relationship. Capability of teachers is not only a single factor to determine students' performance. Abbasi and Mir (2012) from Pakistan, noticed that abilities, ethics, environment have not significant influence on students' performances but for a long duration these have some effect ion performances. Non-significant results were also being supported by Kosgey, Mise, Odera, and Ayugi, (2013) and Bonney, Amoah, Micah, Ahiamenyo, and Lemaire, (2015). Studies showed that the quality of teachers was elevated academic and competence qualification; it did not drive the recital of the students.In the field of educational management, lack of job opportunity has captured serious attention of researchers. Study conducted by AL-Mutairi (2011) and Kang'ahi, Indoshi, Okwach, and Osido, (2012), mentioned that without adequate and trained lecturers, performance of students cannot be improved. Skill, competency are the major contributor for measuring performance of a teacher. For many studies lack of trained teachers is the prime factor behind inadequate learning of students in Nigeria. For Ahunnah (2000),potency of an educational system largely depends upon the quality of its teachers. Achievement of students is largely determined by the quality of the teachers, no matter how efficient the administration is. Ibrahim (2010), pointed out that: "Our educational production has reached a point of diminishing returns especially with too many misfits without adequate manpower skills". In another related review, Arhedo (2007) observed that lecturers should be properly trained in modern technologies to enable them educate students who would be expected to function effectively in a modern work environment and to compete in the global market place". In addition, Okoli (2010) asserted that the excellence of any school system depends on the goals it sets for itself, and achievement of goals in-turn depends on what the teachers are capable of doing. In summary, the researcher observed that in most of higher education in Nigeria, there is poor staffing in terms of quantity and quality. In addition, teachers hardly go for further training, they continue to use skills that are likely to be obsolete as a result of lack of updating knowledge by business teachers. The process of delivering lectures has many associated variables like communication skills, subject matter expertise, and lecturer attendance at classes, teaching skills and lecturer attitude (Akiri and Ugborugbo,2009). The performance of a student has many strong dependencies on the style of teaching of a lecturer (Schacter and Thum, 2004; Adediwura and Tayo, 2007; and Adu and Olatundun, 2007). Moreover, the style of teaching should be in line with the content of any course so that, it can immensely helpful for students in the area of acquiring knowledge.

This implies that, teaching method adopted by a lecturer should be in line with the content of the lesson in other to enhance proper transfer of knowledge. As every learner has different style of interpretation and learning, hence the job of a lecturer is very difficult to align the subject matters w.r.t style and nature of students. Even subject knowledge, attendance, and attitude of a teacher frame the success of his / her students. The speed of learning reflects the performance of a student. For determining the quality of education various studies have been conducted. Factors related with a teacher which affect the performance of student had been highlighted in study conducted by Olaleye (2011). This study also highlighted that teaching style is key factor which determines the success of student. The teaching superiority for achieving success - also known as teacher effectiveness is measured in terms of students' achievement gains. Skills acquisition of students is measured through the use of standardized test to determine the academic growth of students over time. In case of providing quality education without any kind of doubt teachers have great role to play. It is their vital duty to provide education to students w.r.t the syllabus of subjects. Various methods along with traditional lectures like group activities, hands-on experience can be provided to students. Along with these mentoring, counselling, understanding the nature and problems of students always set positive vibes on them (Fraser and Walberg, 2005). Teachers also can be very influential for promoting goals, ethics, standards, behaviours which student should adopt. Thus appropriate time management, endeavour and pledge are most important component of effective teaching. Proper development in the labour market and the socio-economic area can be noticed with proper teaching. Educational, social and poignant needs of students can be fulfilled by proper education. As per Williams (2003), effective teaching is the reflection of their passions. To make classroom environment healthy as well as to make lessons interesting various styles as well as methods are being adopted by lecturers. As per Xuehui, Emily and Tanja (2008), student engagement, association with work has strong dependency on teaching quality. It had been seen in studies that teachers who treat students with friendly nature, able to encourage students. Whereas, teachers who assign lots of burden in terms of home work and always provide lectures without much interactions creates lack of enthusiasm among students. A positive and effectual environment can provide sustainable education. Properly prepared lessons also help to improve capability and curiosity of students. These also help to shape sensible and exigent academic standards which aim to affect performance of students. Lectures are essential to reveal pledge to teacher specialized expansion via attention and turnout at appropriate in-service courses and commitment to a programme of professional study.

Several indices are used to measure the competences of a lecturer. Each lecturer's competence index provides a single measure of lecturer's competence based on a larger number of lecturer's competence measures, such as teacher experience, certification status, academic ability and even stability at school. Although there is ongoing debate about whether objective measures of lecturer competence (such as experience, certification status, quality of the preparation and teacher stability) accurately identify teacher effectiveness in improving students' achievement, recent research has found a statistically significant relationship between these objective measures of quality and gains in students' achievement.

Bangbade (2004) found out that, teachers' attribute have significant relationship with students' academic performance. Such attributes stressed that, Bangbade include teachers' knowledge of the subject matter, communication ability, emotional stability, good human relationship and interest in the job. Rena (2000) further explained that for students to perform well in any examination one of the prerequisites is that, their lecturers must know them and have profound knowledge of their state of physical, intellectual and psychological readiness. Darling-Hammond (2000), said 
that variables which are recognised to be indicative of lecturers' quality which have been examined for their relationship to student learning include, measures of academic ability, years of education, years of teaching experience, mastery of subject matter and teaching knowledge, certification status, and teaching behaviours in the classroom. However, the results of these studies have been mixed with some trends emerging in recent years.

Consequently, for improved lecturers' performance in tertiary education, it is essential that the professional quality of the lecturers should include knowledge of subject matter, pedagogical content knowledge, pedagogy (teaching) and learning, curricular knowledge, teaching experience and certification status (Westera, 2001; Grossman, 2005; Shulman, 2006). Darling-Hammonds (2009) findings indicates a consistent and significant positive relationship between the proportion of well-qualified teachers and student achievement. Lecturers' competence therefore depends on how well a lecturer performs in the classroom to measure how competent the teacher is. (Westera 2001; Grossman 2005) emphasize the importance of Students' performance in relation to competence of a teacher who has a well-developed subject knowledge, pedagogical content knowledge and curriculum knowledge. In Nigerian context, the nature of the learning outcomes depends in turn, on the teacher training curriculum, the level of competence of the principal and that of the mentor in the school which the teacher is assigned.

Empirically, a number of studies have shown that the competences of teachers are strongly related to students' performance. A study had been conducted by Akpan (2014) to find whether ICT proficiency is associated with job efficacy or not for two universities located in Nigeria. From a population of 1,795, 500 university lecturers were randomly being selected for testing two hypotheses. Based on the Job Efficacy questionnaire (ICTCJEQ) responses had been collected. Chisquare and One-way Analysis of variance (ANOVA) revealed that level of ICT competence is not associated with the gender of lecturer. It also mentioned that teaching, publications, interaction skill of a teacher depend on ICT skill. Teachers with high ICT skill perform better in the above mentioned areas compared to teachers having moderate to low skills.

Aregbeyen (2011) also conducted a study with a sample of 400 students and 200 teachers from 40 purposively selected secondary schools in Ibadan metropolis in Nigeria. These schools were categorized into four as public elite schools; public non-elite schools. A composite measure of the quality of teachers covering qualification, experience, patience, creativity and communication skills was utilized. The students' performance was measured by their scores in the two compulsory subjects of English and Mathematics in the general School Leaving Certificate Examination. The empirical methodology combined descriptive and inferential statistical analysis. The results suggested that the observed variations in the students' performance across the four categories of the schools were significantly explained by the differences in the quality of the teachers.

Adegbile and Adeyemi (2008) in their study investigated the relationship that exists between teachers' quality variables and primary school pupils' achievement in English language. The study was a correlational type. The sample of the study consisted of three thousand three hundred and seven (3307) pupils and four hundred and twenty five (425) teachers that were selected through multi-stage sampling technique among primary five pupils and their teachers in South Western Nigeria. The instrument used for the data collection included: Teacher Assessment style Questionnaire (TASQ) and English Language Achievement Test (ELAT). Two research questions were raised in the course of the study. Multiple Regression statistical method was used for data analysis. Results indicated that significant relationship existed among the variables of interest. On a Local Government Areas (LGA) of Osun State, Akinsolu (2010) conducted a study to check the how academic performance of students is associated with relationship between students and teachers. On the basis of 'Quantity and Quality of Teachers and Students' Academic Performance' (QQTSAP), and descriptive study, Twenty -one public secondary schools, one in each LGA from a population of thirty - one LGA in the state were being selected for this study. Results of students from 2000/01 to 2004/05 were used to analyze students' academic performance. The result using ANOVA and spearman Rank Correlation Coefficient revealed that teacher -student ratio were significantly related to students' academic performance. Not only has this, but the qualification, experience of teachers mattered a lot. Hence Nigerian secondary schools need qualified teachers. Arinde (2010) conducted a correlational survey design and Simple random sampling technique to select 3,360 participants out of 8,800 target population. $(3,080$ teachers and 280 principals). On 280 samples and structured data collection instruments (coefficients of reliability after a three-week testretest were found to be 0.75 and 0.78 respectively), the study was conducted. Means and percentage were used to answer six research questions and nine hypotheses. With .05 significance level, Pearson Product Moment Correlation Statistical methods were applied. The result showed that students' academic performance cannot be determined with a single factor of teacher quality alone but may be determined by the degree to which a mixture of educational services is simultaneously provided for them. To find teacher quality in Lagos State Senior Secondary Schools, Nigeria, Gbenu (2012) carried out a research. This study aimed to find out difference in teacher quality among the education districts in the state. Simple random sampling technique was being applied on a sample of 97 . Result revealed that a significant difference existed in terms of teacher's quality among the education districts with the help of analysis of variance (ANOVA). It was not a suitable occurrence on an independent principle on the side of the government. It was observed that difference in teacher quality was mainly present due to the training given to teachers by districts.

\section{Research Method}

\subsection{Design of the Study}

The Correlational survey research design was used for this study. According to Udoh (2005) Correlation research design is used to discover or clarify relationships between heterogeneous variables. 


\subsection{Area of the Study}

The area of this study was South -South Zone of Nigeria. The South-South Zone is just one of the six geopolitical zones in the country. The South-South comprises Akwa Ibom, Bayelsa, Cross Rivers, Delta, Edo and Rivers State. The Zone is bounded to the North by latitude $6^{0} \mathrm{~N}$, to the South by latitude $4^{0} \mathrm{~N}$, to the East by latitude ${ }^{\circ} \mathrm{E}$ and to the West by longitude $6^{\circ} \mathrm{E}$. The zone occupies the southernmost part of Nigeria and is bounded by the Atlantic Ocean. The zone is the major oil producing accounting for much of the revenue accruing to Nigeria from crude oil, palm produce and lots more. Inhabiting this area are the Igbos, the Oros, the annangs, the Ibibios, the Urhobos, the Itzekiris, the Ijaws, Efiks, the Ekois among others. The region under study is predominantly the ever green forest parts of Nigeria. A greater part of it falls within the tropical rain forest (High forest) zone, stretching from Western boundary of Nigeria South-Eastwards through Ibadan and Benin, across the River Niger to the Oban Hills in Cross River State. This forest is made up of hundreds of trees which are usually described as evergreen and which sustains the timber industries in the country. Such trees include the Iroko, Mahogany, Obeche trees among others. South of the rain forest is the fresh water swamp. This belt extends from Lagos across Warri to beyond Port Harcourt, where the soil though not saline, is still water logged. Crop farming is the most important occupation in the upper part of the region. Stock raising and trading are also important here. Today, there is a growing trend of industrialization and viable industries found in Port Harcourt and Calabar. The main natural resources of the zone are petroleum crude (oil) and limestone. These have given rise to the prominent oil mining industries mainly in Rivers, Bayelsa, Delta and Akwa Ibom State and oil refining industry in Port Harcourt and Warri. Another prominent industry in the zone is the cement industry in Calabar. This zone produces most of the petroleum crude which constitutes the major source of government earning, which sustains the economy of Nigeria as a whole. Today, the zone still remains comparatively, under-develop despite protest and agitations.

Traditionally, South -South is made up of a heterogeneous group of people with cultural diversity. The cultural differences of the people are epitomized in songs, dances, food, beliefs and mythology. They are predominantly farmers. Other traditional occupation of the people are fishing, trading, hunting, wood-carving, raffia works, blacksmithing, pottery, iron works, tailoring, arts and craft creations. Educationally, the zone has a lot of educational institutions ranging from primary, secondary and federal tertiary institutions namely: University of Uyo, Uyo; University of Calabar, University of Port-Harcourt, University of Benin, Federal University of Otuoke, Bayelsa State, University of Petroleum, Delta States. Some states within the South-South Zone such as Akwa Ibom and River States are classified as educationally advantaged states. Nonetheless, there are many public and private secondary schools, twelve unity schools, twelve states and Federal Universities, six federal and six states owned among others. The south-south states are rich enough in oil and other natural resources to fund its education. This study covered all the federal universities in South-South, Zone Nigeria. The choice of this zone emanated from the fact that the researchers are from south-South Zone and are conversant with the problems of the area.

The population of the study consisted of all the 5817 final year students in the Faculty of Education in the Federal Universities in South-South Zone of Nigeria. (Source: Faculty records of the Universities, 2016/ 2017 academic session). A sample size of 689 respondents representing $12 \%$ of the population selected from 37 departments, using multi-stage sampling technique. At first, cluster sampling technique was used to cluster the population into six (6) Universities and thirty seven (37) departments. Purposive sampling technique was used in selecting four (4) universities representing $60 \%$ of the six (6) Federal Universities in the South-South Zone. The reason for selecting these four universities is that, they met the criteria for the study since they are the only four federal universities with faculty of education. In the second stage, proportionate sampling technique was used to select 23 departments (60\%) and 689 students representing (12\%) of the population. Simple random sampling technique with Hat and draw method was used to select the 689full-time final year undergraduate students from the selected Federal Universities.

\subsection{Instrumentation}

To collect data for this study, two sets of instruments were used; "Lecturers' Competence Questionnaire (LCQ)" and Universities Student's Skills Acquisition for "Employability Questionnaire (USSAEQ)". Fifty (50) items on Lecturers Competences Questionnaire (LCQ) were developed, while Thirty (30) items were on Universities Students' Skills Acquisition for Employability Questionnaire (USSAEQ) which sought information from students on the employability skills acquired by them, based on communication skills, teamwork skills, problem-solving skills, interpersonal skills, and time management skills. Each variable has six (6) items making a total of thirty (30) items. Both instruments were developed on a four-point rating scale. For (IVQ): VA=Very adequate 4point, A=Adequate-3point, FA=Fairly Adequate-2 point and $\mathrm{NA}=$ Never Adequate-1point. For USSAEQ SA=strongly agree-4point, A=Agreed-3point, $\mathrm{D}=$ Disagree-2point and $\mathrm{SD}=$ Strongly Disagree - 1 point. The instruments were validated by two validates in Measurements and Evaluation in the Department of Educational Foundations, and three validates in Educational Management and Planning, Faculty of Education, University of Uyo. This was done to ensure that the instrument measure accurately what it was purported to measure overtime. To determine the reliability of the instruments, the researcher carried out a trial testing on Lecturers' Variables and Universities Students' Skills Acquisition for Employability. The instruments were administered to fifty (50) students from the population not selected for the study. The scores obtained from the questionnaire were tested using Cronbach Alpha reliability analysis; the reliability indices of .71 and .80 were obtained, high enough, justifying the use of the instruments.

The researchers administered the questionnaire with the help of two briefed assistants. The instruments (LCQ) and (USSAEQ) were administered to students in their respective institutions by the researchers and two briefed research assistants. 689 copies of questionnaire were given out to respondent, 632 representing $92 \%$ return rate, were properly filled and used for the study. The exercise was completed within three weeks. 
Pearson Product Moment Correlation Statistics (PPMC) was used to answer the research question and in testing of null hypotheses at .05 level of significance. In answering research questions, the decision rule by Meyer and Tager -Flusberg (2003) was used to show the strength of relationship of Lectures Competences and universities students' skills acquisition for employability. If the calculated-r value was greater than the critical-r value the null hypothesis was rejected, while if the calculated-r value was less than the critical-r value the null hypothesis was retained.

\section{Data Analysis and Result}

\subsection{Answers to Research Question}

What is the relationship between Lecturers' competences and skills acquisition of Universities students for employability?

\begin{tabular}{|l|l|c|c|c|c|}
\hline Variables & $\begin{array}{l}\sum \mathrm{x} \\
\sum \mathrm{y}\end{array}$ & $\begin{array}{c}\sum \mathrm{x}^{2} \\
\sum \mathrm{y}^{2}\end{array}$ & $\sum \mathrm{xy}$ & $\mathrm{r}-\mathrm{cal}$ & Remark \\
\hline Lecturer competence $(\mathrm{X})$ & 20905 & 1258770 & & & \\
\hline & & & 78942 & .222 & Low Positiverelationship \\
\hline Skills Acquisition (Y) & 37622 & 2623798 & & & \\
\hline
\end{tabular}

Table 1: Result of Pearson Product Moment Correlational Analysis of the Relationship between Lecturers Competence and Skills Acquisition of Universities (632)

Data presented on Table 1.reveals the strength of the relationship between lecturers' competence and skills acquisition. The calculated r-value of .222 indicates a low positive relationship between the two variables. Its value indicates that, there is low, but positive relationship between lecturer's competence and Universities students' skills acquisition for employability. This means that, lecturers' competence can positively impact on acquisition of employability skills by universities students.

\subsubsection{Hypothesis}

There is no significant relationship between lecturers' competences and skills acquisition of Universities students for employability.

\begin{tabular}{|c|c|c|c|c|c|c|}
\hline Variables & $\sum \mathbf{x}$ & $\sum \mathbf{x}^{\mathbf{2}}$ & $\sum \mathbf{x y}$ & $\mathbf{r}-\mathbf{c a l}$ & $\mathbf{r}-\mathbf{c r i t}$ & $\begin{array}{c}\text { Decision at } \\
\mathbf{P = \leq . 0 5}\end{array}$ \\
\hline $\begin{array}{c}\text { Lecturers' } \\
\text { competence } \\
\text { (X) }\end{array}$ & 20905 & 1258770 & & & & \\
\hline & & & & & & \\
\hline $\begin{array}{c}\text { Skill } \\
\text { Acquisition } \\
\text { (Y) }\end{array}$ & 37622 & 2623798 & 78942 & .222 & .088 & $*$ \\
\hline
\end{tabular}

Table 2: Result of Analysis of Pearson Product Moment Correlation on Relationship between Lecturers Competence and Skill Acquisition of Universities Students $(\mathrm{N}=632)$

$*$ Significant at $\mathrm{P}=\leq .05 ;$ Level $=.088 ; \mathrm{d} f=630$

Result in Table 2 revealed that the calculated - $r$ value of .222 is greater than the critical- $r$ value of .088 at 0.5 level of significance with 630 degree of freedom. The result is significant; therefore, the null hypothesis which states that 'there is no significant relationship between lecturers' competence and skill acquisition of Universities students for employability' was rejected. The result implies that lecturers' competence relates significantly with skill acquisition of Universities students for employability.

\section{Discussion of Findings}

\subsection{Lecturers Competences and Skill Acquisition of Universities Students for Employability}

The result of the analysis presented in hypothesis 0ne revealed that lecturers' competences is significantly related to skills acquisition of universities students for employment. The result indicates that a significant relationship present between lecturers' proficiency and skills acquisition of universities students for employability. The outcome leads to the acceptance of alternative hypothesis. The result has shown that capacity of apprentice to transfer knowledge, skills, educate, teach, guide, direct, train, and evaluate have strong relation with employability. It has been highlighted that communication skills, ability to learn, social interactions, problem solving, working with ICT or other support tools which indicate the employability factor of a student actually functions of a skilled mentor. It has been clearly mentioned that teaching capability influence the chance of getting job for the South-south zone, Nigeria's university students. The outcome of this study is quite similar with the study of Akpan (2014), where the author did not find any difference 
between a male and a female teacher in their ICT skill. Teachers with strong ICT skill found to be more effectual in many areas like - research publication, communication and recordkeeping, delivering lectures etc compared to others having moderate to low ICT Skill. The finding of this is also in agreement with study by Gbenu (2012) who study the relationship between teacher competences in Lagos State Senior secondary Schools, Nigeria. The results revealed that a significant difference exist in terms of teachers competence among the education district in the state. This result implies that, student's performance is strongly affected by teacher quality. In other words, teachers teaching qualities can translate instruction to skills through effective manipulation of curriculum, using appropriate instructional facilities. Therefore, lecturers' competences which include, classroom management, content delivery, proficiency in communication skills, students-lecturer relationship skills, classroom participatory skills, mastery of subject matter, lesson presentation etc., relate to Universities students' skills acquisition for employability.

A germane reason for this finding is that, lecturers' competences are important aspect of and the needed skills to help the students gain more knowledge in both theories and practices of learning. The implication is that, lecturers' competences in the learning process will drive and help the students to achieve better skills. In contrast, if lecturer's competencies such as knowledge, creativity, discipline, communication, preparation are maintained, student acquisition for employability will increase but if lecturers' competences are not adequate, it will definitely lead to a poor acquisition of employability skills by the Universities students. Lecturers and students must have a favourable relationship with their lecturers, for effective teaching/learning situation to evolve. That is, there must be an atmosphere of cordiality which breeds trust on lecturers by students. It is only when these situations exists that student can acquire employability skills through interactions with other lecturers in and outside the classrooms. The classroom climate must also be conducive to engender result-oriented teaching and learning.

\section{Conclusion}

It was concluded based on the finding that, Lecturers' competence in teaching and learning process would drive the students, especially at the universities 'level, to achieve better performance and also help them to acquire the necessary skills needed at the workplace. It was recommended that, Federal Government, corporate organizations and individuals should train and retrain lecturers by providing avenues for research advancement. Such avenue will encourage capacity development of lecturers in $21^{\text {st }}$ century teaching strategies and best methods for instructional management.

\section{References}

i. Abbasi, A.S. and Mir, G.M. (2012).Impact of Teacher's Ability, Student's Work Ethics and Institutional Environment on Student Performance of University of Gujrat. Middle-East Journal of Scientific Research. Vol. 12, No. 4, 572-579.

ii. Adegbile, J. A. and Adeyemi, B.A. (2008), Influence of Teacher Quality Variables on Nigerian Primary School Pupils' Achievement in English Language. The African Symposium.

iii. Ahunanya, S. I and Ubabudu, M.C. (2006). Enrolment facilities and financial allocation in Lagos Higher Education: Implication for quality graduates. Nigerian Journal of education Administration and Planning, 6 (1): 153-164

iv. Akiri, A. A. (2013). Effects of Teachers' Effectiveness on Students' Academic Performance in Public Secondary Schools; Delta State - Nigeria. Journal of Educational and Social Research, 105.

v. Akpan, C. P. (2004). ICT Competence and Lecturers' Job Efficacy in Universities in Cross River State, Nigeria. International Journal of Humanities and Social Science 4 (10), 261 - 266.

vi. Akinsolu, A. O. (2010). Teachers and Students' Academic Performance in Nigerian Secondary Schools: Implications for Planning. Florida Journal of Educational Administration and Policy. 3 (2): 86-103.

vii. Al-Mutairi, A. (2011). Factors Affecting Business Student' Performance in Arab Open University: The Case of Kuwait. International Journal of Business and Management. Vol. 6, No. 5, 146-155.

viii. Aregbeyen, O. (2011). Quality of Teachers and Students' Performance: Evidence from Schools in Ibadan Metropolis, Nigeria. Ozean Journal of Economics Education, Taylor and Francis Journals, 35, 311-329.

ix. Arinde, M. R. (2010). Educational Services, Teacher quality and students' Academic performance in public Senior Secondary Schools, North Central Zone, Nigeria. An unpublished Ph.D Thesis. University of Ilorin, Ilorin Nigeria.

x. Bangbade,J. O. (2004) 'Effects of subjects matter knowledge in the teaching and learning of Biology and Physics'. Teaching and Teacher Education: 109-102.

xi. Darling-Hammond, L. (2000).Teacher Quality and Student Achievement: A Review of State Policy Evidence. Education Policy Analysis Archives. Vol. 8, No. 1, 1-44.

xii. Darling-Hammond, L. and Frelow M. (2002). Constructing 21st-century teacher education. Journal of TeacherEducation, 57 (2).

xiii. Ganyaupfu, E.M. (2013). Factors Influencing Academic Achievement in Quantitative Courses among Business Students of Private Higher Education Institutions. Journal of Education and Practice. Vol. 4, No. 15, 57-65.

xiv. Gbenu, J. P. (2012). State of Teachers Quality in Lagos State Senior Secondary Schools. Nigeria: Implication for Educational Planning. Online Journal of Education Research. 1 (7): 125-131

xv. Grossman, P. A. (2005). Quality Education of Basic Education. A comparative model. Nigerian Journal of Educational Research and Evaluation, 1 (4): 87-89.

xvi. Hakim, A. (2015). Contribution of Competence Teacher (Pedagogical, Personality, Professional Competence and Social) On the Performance of Learning. The International Journal of Engineering and Science. Vol. 4No.01-12. 
xvii. Kosgei, A., Mise, J. K., Odera, O., and Ayugi, M. E. (2013). Influence of Teacher Characteristics on Students' Academic Achievement among Secondary Schools. Journal of Education and Practice.Vol. 4, No. 3, 76-82.

xviii. Liakopoulou, M. (2011).The Professional Competence of Teachers: Which qualities, attitudes, skills and knowledge contribute to a teacher's effectiveness? International Journal of Humanities and Social Science.Vol. 1, No. 21,66-78.

xix. Muzenda, A. (2013). Lecturers' Competences and Students' Academic Performance. International Journal of Humanities and Social Science Invention. Vol. 3, Issue. 1, 06-13.

xx. Okolie, L. (2010). Entrepreneurship Education course duration and students' inculcation of entrepreneurial skills in University of Nigeria, Nsukka. Journal of Education, 3(1):76-79.

xxi. Suchuman, N. (2006). Information Software for the Library. New York: Dell Publisher.

xxii. Sultan, S. and Shafi, M. (2014). Impat of Perceived Teachers' Competence on Student's Performance: Evidence for Mediatir/ Moderating Role of Class Environment. Journal on Educational Psychology. Vol. 8, No. 1, 10-18. UndangUndang R.I. Nomor 14 Tahun 2005 Tentang Guru dan Dosen. (2006). Jakarta: BP.

xxiii. Wamala, R., and Seruwagi, G. (2013). Teacher Competence and the Academic Achievement of Sixth Grade Students in Uganda. Journal of International Education Research. Vol. 9, No. 1, 83-90.

xxiv. Žeravíková, I., Tirpáková, A. Markechová, D. (2015). The Analysis of Professional Competencies of a Lecturer in Adult Education. Springer Plus. 4:234, 1-10. 